\title{
Competitive interactions between the alien invasive annual grass Avena fatua and indigenous herbaceous plants in South African Renosterveld: the role of nitrogen enrichment
}

\author{
Gyan P. Sharma $\cdot$ Sara A. Muhl • \\ Karen J. Esler • Suzanne J. Milton
}

Received: 30 June 2009/Accepted: 20 February 2010/Published online: 7 March 2010

(C) Springer Science+Business Media B.V. 2010

\begin{abstract}
Nitrogen enrichment may play a role in successful invasion of indigenous South African mediterranean shrublands by alien invasive annual grasses. To test the hypothesis that an increase in nitrogen would result in a greater increase in biomass for an alien annual grass than for various indigenous plant functional groups, we conducted a field study in Western Cape Renosterveld shrubland fragments, surrounded by wheat or vinyards, to assess alien grass abundance in relation to soil nitrogen availability. Significant decreases in invasive annual grass Avena fatua cover and soil nitrogen were observed from the edges to the interior of Renosterveld habitat fragments and there was a significant positive relationship between Avena fatua cover and soil nitrogen. In addition, Avena fatua was grown in competition with three indigenous species of different functional types, an annual forb (Dimorphotheca pluvialis), a geophyte (Oxalis purpurea) and an indigenous perennial grass (Tribolium uniolae) at three concentrations of soil nitrogen in a pot experiment. Results revealed
\end{abstract}

G. P. Sharma $(\varangle) \cdot$ S. A. Muhl · K. J. Esler

Centre for Invasion Biology and Department of Conservation Ecology and Entomology, Stellenbosch University, Private Bag X1, Matieland 7602, South Africa e-mail: gyanprakashsharma@gmail.com

\section{S. J. Milton}

DST Centre of Excellence, Percy FitzPatrick Institute of African Ornithology, University of Cape Town,

Rondebosch 7701, South Africa that the alien grass Avena fatua had significant increases in biomass when nitrogen was added, whereas the indigenous species did not. Alien grass competition significantly influenced performance of the annual forb and the indigenous grass but did not affect the geophyte. Results suggest the prioritization of hierarchical management options for the different functional groups in Renosterveld in response to invasive grasses. Nutrient enrichment through run off must be restricted to conserve remnant Renosterveld fragments.

Keywords Avena fatua $\cdot$ Biomass · Competition - Nitrogen enrichment . Renosterveld

\section{Introduction}

Grasses established beyond their natural ranges have been identified as a particular set of invasive species that collectively threaten the regional and even global aspects of ecosystem function (Knapp et al. 1996). A notable example is the invasion of Californian grassland by the annual Mediterranean grass Bromus tectorum which has transformed nearly 10 million hectares of native grasslands, and significantly impacted the regions economy (Corbin and D'Antonio 2004). Large-scale invasion of alien grasses from other continents and from within the continent is 
recognised as a threat to the indigenous flora of South Africa (Milton 2004). Many grasses are characterised by high population growth rates, short generation times, abundant seed production and highly effective seed dispersal (Rejmánek and Richardson 1996; Westman 1990). Annual invasive grasses in particular have evolved to produce large volumes of seed, and have rapid growth rates and fast germination times (Ferrandis et al. 2001; Gustafson et al. 2004; Hunter and Omi 2005) thus allowing them to overcome barriers to invasion.

The present study was conducted in the mediterranean climate zone of South Africa in Swartland Shale Renosterveld, a critically endangered habitat type of the globally significant Fynbos Biome (Mucina and Rutherford 2006). Renosterveld in the west coast lowlands of the biome has been exposed to a high degree of transformation, fragmentation through ploughing of almost all $(\approx 95 \%)$ arable land leaving only isolated patches of natural vegetation on rocky ground, and invaded by alien plants (Low and Rebelo 1998; Newton and Knight 2005; von Hase et al. 2003). In addition to fragmentation, several forms of disturbance are present in the Renosterveld environment. Natural disturbances include the activity of animals and fire while anthropogenic activities introduce additional forms of disturbance such as grazing, altered fire regimes and crop production with associated ploughing, drift of fertilizers, pesticides (through runoff and during initial application) and alien propagules.

Invasion by alien plants, particularly European winter-growing grasses such as Avena, Briza, Bromus, Hordium and Lolium, is widespread (Milton 2004; Shiponeni and Milton 2006) and possibly facilitated by increasing concentrations of carbon dioxide, phosphorous and nitrogen that benefit alien over native species (Clements 1983; Zavaleta 2006). Several studies have demonstrated that nutrients may play a role in the competitive interactions between native and alien grass species (Brooks 2003; Groves et al. 2003, Suding et al. 2004; Anderson and Innouye 2001), for example Australian native grasses proved to be less competitive when grown at increased nutrient levels than those introduced from Europe (Groves et al. 2003; Brooks 2003; Corbin and D'Antonio 2004).

Both nitrogen and phosphorus are likely to control rates of growth in Mediterranean ecosystems (Read and Mitchell 1983; Stock and Allsopp 1992). We chose to focus this study on the influence of increased nitrogen levels, since there is greater likelihood of nitrogen enrichment via fertilizer drift (Hegarty et al. 1994) and runoff of water from croplands. Increased nitrogen levels caused by fertilizers can increase growth and abundance of annual grasses, thus allowing them to out-compete perennial species (Paschke et al. 2000; Yelenik et al. 2004).

We hypothesized that alien grasses would tend to invade natural habitat fragments down slope of croplands because of nutrient enrichment caused by runoff from the adjacent fields. We selected the European annual grass Avena fatua which is common in remnant Renosterveld patches near wheat-lands, and is a typical annual alien invasive grass with respect to its phenology and physiognomy. To address the questions of how soil nitrogen at different concentrations might influence the productivity of this grass, and how nitrogen enrichment may give it a competitive advantage over other indigenous Renosterveld plant species we divided our study into two components, (1) a field based study and (2) a green house experiment.

Specifically we tested the hypotheses that (1) soil nitrogen and $A$. fatua density decrease with distance from crop land in field, and (2) that increased soil nitrogen gives A. fatua a competitive advantage over indigenous herbaceous plant species through a green house experiment.

\section{Methods}

Field study

The field study was conducted in three Renosterveld shrubland fragments situated in Jan Briers Louw Geometric Tortoise Reserve $\left(33^{\circ} 45^{\prime} 45^{\prime \prime} \mathrm{S}\right.$ and $\left.18^{\circ} 50^{\prime} 07^{\prime \prime} \mathrm{E}\right)$, Muldersbosch Farm $\left(33^{\circ} 55^{\prime} 39^{\prime \prime} \mathrm{S}\right.$ and $18^{\circ} 46^{\prime} 37^{\prime \prime} \mathrm{E}$ ) and Paul Cluver Estate (located within the Kogelberg Biosphere Reserve, $34^{\circ} 09^{\prime} 05^{\prime \prime} \mathrm{S}$ and $19^{\circ} 02^{\prime} 08^{\prime \prime} \mathrm{E}$ ) (Mucina and Rutherford 2006). Renosterveld is largely confined to fertile shale and granite soils (Boucher and Moll 1981; Low and Rebelo 1998) with annual rainfall ranging from 250 to $600 \mathrm{~mm}$. The vegetation type consists predominantly of asteraceous shrubs, geophytic species belonging to the Iridaceae, Liliaceae and Orchidaceae, and grasses (Low and 
Rebelo 1998; Moll and Bossi 1984). Site selection was based on a few specific criteria: sites needed to be down-slope of active agricultural fields, where there was no unnatural grazing pressure for at least 10 years, no fires within the previous 10 years, and had an invasion front of alien invasive grasses (specifically A. fatua). At each site three belt transects with 13 quadrats $(3 \times 3 \mathrm{~m})$, of similar orientation were established running perpendicular to the Renosterveld patch-agricultural boundary. Quadrats along the belt transect were sampled for $A$. fatua cover (Wikum and Shanholtzer 1978) and soils for total nitrogen (\%) (total $\mathrm{N}$ by complete combustion using a Eurovector Euro EA Elemental Analyzer).

\section{Study species}

The alien grass, Avena fatua (Poaceae), originally from the Mediterranean and/or Eurasia, is a robust annual grass with unbranched clums $(250-850 \mathrm{~mm}$ tall) and erect stems bearing panicles of spikelets (15-30 mm long). It flowers in spring (from August to November in South Africa). This species is highly competitive, producing large numbers of seeds that have a staggered germination (Grabandt 1985). It is common in disturbed areas such as gardens and along the edges of gravelled and tarred roads (van Oudstshoorn 1992), and is a weed in irrigated cultivated landscapes. It is commonly found in damp areas and sandy soils (van Oudstshoorn 1992). This European annual grass is frequently encountered in Renosterveld fragments adjacent to wheat fields and vineyards.

The indigenous species included a geophyte, a grass and an annual forb. The geophyte, Oxalis purpurea (Oxalidaceae), is a bulbous perennial with short rhizomes leading to its bulbs and is capable of vegetative reproduction. It is stemless, with compound leaves borne in basal rosettes at ground level, and is widespread from Namaqualand to Caledon. Tribolium uniolae (Poaceae) is an annual or perennial grass, and is common to winter rainfall areas such as the karoo and fynbos biomes (Watson and Dallwitz 1992). The annual forb, Dimorphotheca pluvialis (Asteraceae), is a daisy common in the Namaqualand region of the Western Cape. Seeds of A. fatua, T. uniolae and $O$. purpurea were collected from the Stellenbosch, South Africa. D. pluvialis seeds were purchased from a local nursery.
Greenhouse experiment

We tested the effect of increasing nitrogen on the biomass of invasive grass and the three indigenous species in monoculture. Above ground biomass of individuals of each species was measured at the end of the experiment. We also tested competitive interactions between Avena fatua and the indigenous grass, geophyte and annual forb species under three levels of nitrogen $(\mathrm{N})$ in terms of biomass. The study was carried out under controlled conditions in a greenhouse, using soils collected from the Renosterveld habitat. Field soil was used in order to retain natural microbial activity; this was taken at a depth of $10 \mathrm{~cm}$ from the interior of all the Renosterveld fragments (approximately $35 \mathrm{~m}$ from the edge). Soils were sieved through a $1 \mathrm{~mm}$ sieve to remove as many seeds of non-target species as possible.

Nitrogen was added in the form of limestone ammonium nitrate (LAN) solution once (Agenbag and De Villiers 1989; Ratlabala 2003) and nutrient levels were set at control (no $\mathrm{N}$ addition), low $\mathrm{N}$ (Control $+100 \mathrm{mg} \mathrm{N}$ per pot) or high $\mathrm{N}$ (Control $+200 \mathrm{mg} \mathrm{N}$ per pot); other soil variables remained constant throughout the experiment, the control pots received the same amount of water that was required to maintain the similar level of moisture for all the pots. Nutrient addition levels were determined according to accepted farming practices (Bennie Diedericks, personal communication). Watering commenced on 22 July 2006 at 3 min of fine spray twice a day and the experiment ran from 25 July to 15 September 2007. Average greenhouse temperatures ranged from 15 to $25^{\circ} \mathrm{C}$. As temperatures increased, watering was adjusted accordingly. Pots were randomly rotated on a weekly basis and progress was monitored twice a week. Plants were harvested from 15 September to 20 September 2006 once there were some indications of senescence. Any treatments where there was a mortality of plants were excluded as mortality could not be conclusively explained by competitive interactions. Plant material was then oven dried at $70^{\circ} \mathrm{C}$ for $48 \mathrm{~h}$ and thereafter dry shoot mass was determined.

All the species were raised from seeds (or in the case of Oxalis purpurea, bulbs) on the above mentioned soil nitrogen levels (viz. control, low $\mathrm{N}$ and high $\mathrm{N}$ ). With one set a monoculture experiment and with another set a competition experiment was 
established. For the monoculture experiment the plants were harvested at the end of the experiment. For the competition experiment just after the emergence (sprouting) of all the species, A. fatua plants were introduced into each pot and above ground biomass was estimated at the end of the experiment.

\section{Statistical analysis}

For the green house experiments ANOVA was performed to test the effect of nitrogen on above ground biomass of $A$. fatua and indigenous species in monoculture. Data were also analyzed by two-way ANOVA using nitrogen level and competition as independent variables and native species as dependent factor. Differences in biomass among the species at different nitrogen levels and in competition with A. fatua were tested by Tukey's HSD test (at $P<0.05$ ). For the field study, a linear correlation regression was performed to assess the relationship between Avena fatua cover (\%) and total soil nitrogen (\%) from the edge to interior of fragments. All the statistical analyses were performed using the SPSS statistical package (SPSS 1997 Inc., Chicago, USA).

\section{Results}

Field results

A. fatua cover and total nitrogen varied from $0-100 \%$ to $0.04-0.27 \%$ respectively. Significant negative relationships between both $A$. fatua cover $\left(R^{2}=0.57\right.$; $P=0.01)$, and percent total nitrogen $\left(R^{2}=0.30\right.$; $P=0.04$ ), were observed with distance from the edge to the interior of all the Renosterveld fragments (Fig. 1). A significant positive relationship was observed between A. fatua cover and total nitrogen $\left(R^{2}=0.56 ; p=0.03\right)$.

Responses of A. fatua and indigenous species to increased nitrogen under greenhouse conditions

The alien grass $A$. fatua significantly benefited from addition of nitrogen as compared to the native species (Fig. 2). A. fatua shoot mass increased from $15.9 \mathrm{~g}$ (control) to $25.3 \mathrm{~g}$ (high nitrogen) and was significantly different among different nitrogen levels $\left(F_{2,24}=17.26 ; P<0.001\right)$ (Fig. 2). However, all

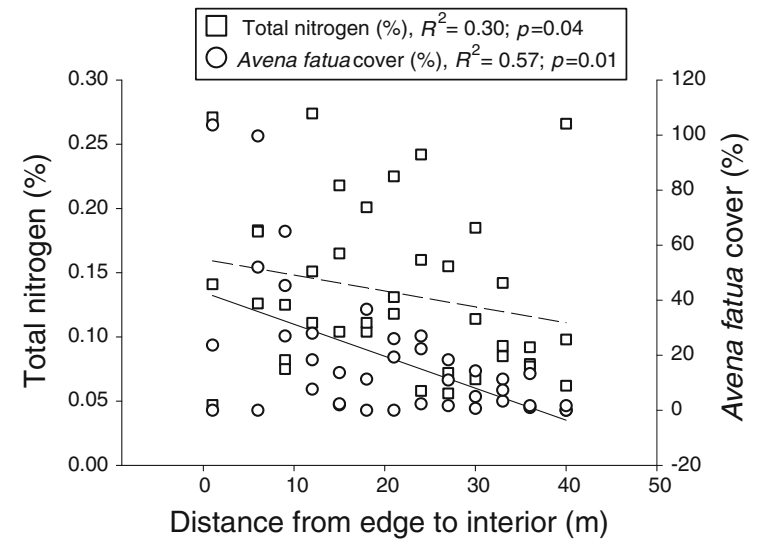

Fig. 1 Variation in Avena fatua cover (\%) and total soil nitrogen $(\%)$ from edge to interior of all the Renosterveld shrubland fragments studied $(n=39)$

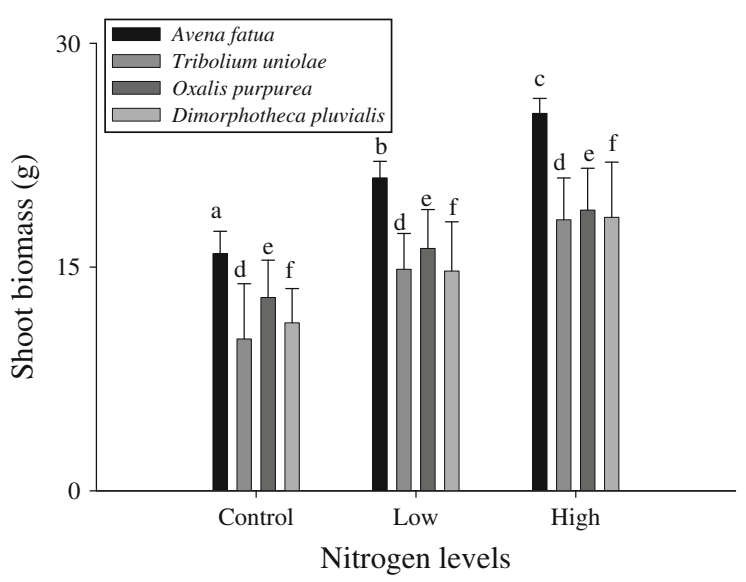

Fig. 2 Above ground biomass of Avena fatua and three indigenous Renosterveld species at different concentrations of nitrogen enrichment in monoculture. The graphs suffixed with different letters are significantly different from each other according to Tukey's HSD test at $P<0.05$ between the nitrogen treatments (bars indicate $\pm \mathrm{SE}$ )

the indigenous species did not differed significantly in monoculture at different concentrations of nitrogen enrichment (Fig. 2).

Responses of indigenous species to nitrogen and competition under greenhouse conditions

The competitive effect of A. fatua on D. pluvialis was highly significant in that it reduced the biomass of D. pluvialis significantly (Tables 1,2 ), however nitrogen addition did not have a significant effect on D. pluvialis biomass either with or without 
Table 1 Biomass of Renosterveld indigenous species in presence and absence of Avena fatua at different nitrogen nutrient levels (values in parenthesis are $\pm \mathrm{SE}$ )

\begin{tabular}{|c|c|c|c|c|c|c|}
\hline \multirow{3}{*}{$\begin{array}{l}\text { Nitrogen } \\
\text { level }\end{array}$} & \multicolumn{6}{|l|}{ Avena fatua } \\
\hline & \multicolumn{3}{|l|}{ Present } & \multicolumn{3}{|l|}{ Absent } \\
\hline & $\begin{array}{l}\text { Tribolium } \\
\text { uniolae }\end{array}$ & $\begin{array}{l}\text { Oxalis } \\
\text { purpurea }\end{array}$ & $\begin{array}{l}\text { Dimorphotheca } \\
\text { pluvialis }\end{array}$ & $\begin{array}{l}\text { Tribolium } \\
\text { uniolae }\end{array}$ & $\begin{array}{l}\text { Oxalis } \\
\text { purpurea }\end{array}$ & $\begin{array}{l}\text { Dimorphotheca } \\
\text { pluvialis }\end{array}$ \\
\hline Control & $0.03^{*}(0.02)^{\mathrm{a}}$ & $0.13(0.06)^{\mathrm{a}}$ & $0.15^{*}(0.05)^{\mathrm{a}}$ & $2.85^{*}(0.55)^{\mathrm{a}}$ & $0.15(0.06)^{\mathrm{a}}$ & $11.76^{*}(4.42)^{\mathrm{a}}$ \\
\hline Low & $0.31^{*}(0.15)^{\mathrm{b}}$ & $0.05^{*}(0.03)^{\mathrm{a}}$ & $0.23^{*}(0.08)^{\mathrm{a}}$ & $2.85^{*}(0.43)^{\mathrm{a}}$ & $0.13^{*}(0.04)^{\mathrm{a}}$ & $15.12^{*}(3.88)^{\mathrm{a}}$ \\
\hline High & $0.53^{*}(0.25)^{\mathrm{b}}$ & $0.06^{*}(0.02)^{\mathrm{a}}$ & $0.60^{*}(0.25)^{\mathrm{b}}$ & $3.45^{*}(0.54)^{\mathrm{a}}$ & $0.18 *(0.07)^{\mathrm{a}}$ & $17.54 *(5.56)^{\mathrm{a}}$ \\
\hline
\end{tabular}

Values affixed with asterisk $\left(^{*}\right)$ are significantly different from each other in row according to Tukey's HSD test at $P<0.05$ between the Avena fatua presence and absence

The alphabetical superscripts in column with different letters are significantly different from each other according to Tukey's HSD test at $P<0.05$ at different nitrogen levels

Table 2 Summary of two-way ANOVA of native Renosterveld species (Tribolium uniolae: Tu, Oxalis purpurea: Op, Dimorphotheca pluvialis: Dp), with and with-out A. fatua competition at different nitrogen levels

\begin{tabular}{llrc}
\hline Variables & Native species & $F_{2,24}$ & \multicolumn{1}{l}{$P$} \\
\hline Nitrogen level (N) & $\mathrm{Tu}$ & 156.7 & 0.58 \\
& $\mathrm{Op}$ & 17.3 & 0.68 \\
& $\mathrm{Dp}$ & 98.7 & 0.89 \\
Competition (C) & $\mathrm{Tu}$ & 1018.5 & $<0.001$ \\
& $\mathrm{Op}$ & 118.4 & $<0.05$ \\
& $\mathrm{Dp}$ & 7282 & $<0.001$ \\
$\mathrm{~N} \times \mathrm{C}$ & $\mathrm{Tu}$ & 17.3 & $<0.001$ \\
& $\mathrm{Op}$ & 16.1 & $<0.001$ \\
& $\mathrm{Dp}$ & 102.8 & $<0.001$ \\
\hline
\end{tabular}

A. fatua competition (Tables 1,2). The number of inflorescences produced by $D$. pluvialis was far greater without competition (Table 3). A. fatua depressed biomass of the geophyte (O. purpurea), reducing the biomass from 0.13 to $0.05 \mathrm{~g}$ under competition. The competitive affect of $A$. fatua on the biomass of $T$. uniolae was significant, although at high nitrogen level the biomass of $T$. uniolae was significant from the control (Tables 1, 2). Two-way ANOVA indicated a significant effect of competition alone and in combination with nitrogen level and competition on native species (Table 2). The response of species varied across the different nitrogen levels and A. fatua competition as indicated by two-way interaction of nitrogen and A. fatua competition, nitrogen level alone did not significantly affect the native species (Table 2).
Table 3 Mean number of inflorescence in Dimorphotheca pluvialis in presence and absence of Avena fatua at different nitrogen nutrient levels (values in parenthesis are \pm SE)

\begin{tabular}{llr}
\hline Nitrogen level & \multicolumn{2}{l}{ Avena fatua } \\
\cline { 2 - 3 } & Present & Absent \\
\hline Control & $0.57(0.12)^{\mathrm{a}}$ & $2.29(0.5)^{\mathrm{c}}$ \\
Low & $0.71(0.09)^{\mathrm{a}}$ & $6.6(0.46)^{\mathrm{d}}$ \\
High & $1.08(0.08)^{\mathrm{b}}$ & $8.29(1.21)^{\mathrm{e}}$ \\
\hline The alphabetical superscripts in row and columns with \\
different letters are significantly different from each other \\
according to Tukey's HSD test at $P<0.05$
\end{tabular}

\section{Discussion}

In this study, we show how nitrogen is a possible driving factor for increased alien grass cover in Renosterveld fragments. An alien grass which is favoured by nutrient enrichment competes with the indigenous vegetation which does not benefit from increased nitrogen availability under conditions of nitrogen enrichment.

Nutrient inputs, in the form of fertilizer drift from adjacent farm lands, may play an important role in the invasion of Renosterveld fragments by invasive alien grasses. The concurrent decline of alien grass (A. fatua) cover and nitrogen concentration from Renosterveld fragment edges to the interior suggests that invasion of A. fatua is dependent, at least partly, on nitrogen enrichment. It also implies that species at fragment edges face the dual and potentially synergistic challenges of competition from alien grasses and nutrient enrichment. A. fatua grows far taller than any of the native species in the present study, potentially enabling 
it to out-compete native species for light and space (Badgery et al. 2005). Nitrogen enrichment may disproportionately affect the low stature species overtopped by A. fatua. Much of the diversity in Renosterveld comprises low-stature growth forms, such as geophytes and annuals, making them vulnerable to such situations. In addition, seedlings of shrub and grass species are also potentially vulnerable. Prevailing conditions at the fragment edges subsequently lead to alien grass encroachment and the loss of herbaceous species (Carroll et al. 2003).

To mimic the field study our green house experiment tested whether increased nitrogen alters the biomass of an alien grass and native species (Dimorphotheca pluvialis, Oxalis purpurea and Tribolium uniolae) grown alone and in competition. We demonstrated that biomass of the indigenous species T. uniolae, D. pluvialis, O. purpurea did not significantly increase with addition of nitrogen whereas, the invasive annual $A$. fatua grows extensively, significantly increasing in biomass with an increase in nitrogen. This observation is in line with numerous other studies which have concluded that, with high nitrogen availability, alien grasses are able to produce more biomass and outcompete native grasses that are adapted to low nutrient conditions (Brooks 2003; Defalco et al. 2003; Hunter and Omi 2006; Badgery et al. 2005).

Further, competition from A. fatua, even without nitrogen enrichment, significantly depressed T. uniolae biomass. A. fatua clearly benefits significantly from nutrient enrichment in Renosterveld soils where the indigenous grass $T$. uniolae does not. Native Renosterveld grasses do not occur at high densities, neither do they increase in biomass as rapidly as annual alien invasives under situations of nitrogen enrichment; therefore their competitive ability is limited in these situations.

Results from our study indicate a very clear competitive effect of alien grasses on an indigenous grass and an indigenous annual, however the geophyte did not respond in the same way. Biomass of the geophyte $O$. purpurea was significantly affected by competition while in the absence of competitors increased nitrogen did not alter biomass significantly suggesting that nitrogen is not a strong driver in growth of this species. Biomass of the annual D. pluvialis was more strongly influenced by nitrogen levels in presence of A. fatua. The number of inflorescences produced by indigenous annual D. pluvialis plants nearly doubled from "no added nitrogen" to "high nitrogen with competition" while inflorescences increased nearly fourfold from "no nitrogen" to "high nitrogen without competition". A. fatua clearly depressed reproductive output of indigenous annual species and the competitive impact was far more profound than the nutrient effect for D. pluvialis. Such reproductive decline may ultimately affect the species presence with time and is suggestive of long-term changes in species composition of the Renosterveld. Our results are similar to those of an Australian study where native grasses performed poorly in the mixed stands under increased levels of nutrients while/and perennial grasses were unable to compete with the introduced annual and perennial species under increased nitrogen conditions (Groves et al. 2003). In other study alien grass Deschampsia flexuosa was shown to out-compete the native shrubs Calluna vulgaris, Erica tetralix and Molinia caerulea under increased nutrient levels (Aerts and Berendse 1988; Aerts et al. 1990). van den Berg et al. (2005) also reported that increased nitrogen inputs are of major importance for the increased dominance of tall grasses in coastal dune grasslands of Oostvoorne of the Dutch coast, Western Europe.

Our results suggest that hierarchal management options need to be developed for different Renosterveld functional groups as they respond variably to increased nutrient competition with invasive species. It would appear that Renosterveld edges subject to inputs from adjacent agriculture activity require special management attention. Practical measures are: maintenance of intact indigenous vegetation cover; minimization of fertilizer drift onto fragments during application and diversion of nutrient-rich run-off water.

Acknowledgments Karen Esler (KJE), Gyan P. Sharma (GPS) and Sara A. Muhl (SAM) gratefully acknowledge funding from Center of Excellence for Invasion Biology (C.I.B), Stellenbosch University, South Africa and BIOTA Southern Africa project (Promotion numbers 01 LC 0024A and 01 LC 0624A2. GPS and KJE also acknowledge the National Research Foundation (NRF), Pretoria for Indo-South Africa funding, No. UID 67549. Martin Kidd is thanked for assisting SAM in data analysis. We are also grateful to the anonymous referees for their valuable comments on previous versions of this manuscript. 


\section{References}

Aerts R, Berendse F (1988) The effect of increased nutrient availability on vegetation dynamics in wet heathlands. Vegetation 76:63-69

Aerts R, Berendse F, De Caluwe H, Schmidt M (1990) Competition in heathland along an experimental gradient of nutrient availability. Oikos 57:310-318

Agenbag GA, De Villiers OT (1989) The effect of nitrogen fertilizers on the germination and seedling emergence of wild oat (A. fatua L.) seed in different soil types. Weed Res 29:239-245

Anderson JE, Innouye RS (2001) Landscape-scale changes in plant species abundance and biodiversity of a sagebrush steppe over 45 years. Ecol Monogr 71:531-556

Badgery WB, Kemp DR, Michalk DL, King WMCG (2005) Competition for nitrogen between Australian native grasses and the introduced weed Nassella trichotoma. Ann Bot 96:799-809

Boucher C, Moll EJ (1981) South African mediterranean shrublands. In: di Castri F, Goodall DW, Specht RL (eds) Ecosystems of the world, vol 11. Mediterranean-type shrublands. Elsevier, Amsterdam, pp 233-248

Brooks ML (2003) Effects of increased soil nitrogen on the dominance of alien annual plants in the Mohave Desert. J Appl Ecol 40:344-353

Carroll JA, Caporn SJM, Johnson D, Morecroft MD, Lee JA (2003) The interactions between plant growth, vegetation structure and soil processes in semi-natural acidic and calcareous grasslands receiving long-term inputs of simulated pollutant nitrogen deposition. Environ Pollut 121:363-376

Clements A (1983) Suburban development and resultant changes in the vegetation of the bushland of the northern Sydney region. Aust J Ecol 8:307-319

Corbin J, D'Antonio CM (2004) Effects of invasive species on soil nitrogen cycling: implications for restoration. Weed Tech 18:1464-1467

Defalco LA, Bryla VS, Nowak RS (2003) Are Mojave Desert annual species equal? Resource acquisition and allocation for the invasive grass Bromus madritensis susp. rubens (Poaceae) and two native species. Am J Bot 90:10451053

Ferrandis P, Herranz JM, Martinez-Sanchez JJ (2001) Response to fire of a predominantly transient seed bank in a Mediterranean weedy pasture (eastern-central Spain). Ecoscience 8:211-219

Grabandt K (1985) Weeds of crops and gardens. CIBA-GEIGY (Pty) Limited, Johannesburg

Groves RH, Austin MP, Kaye PE (2003) Competition between Australian native and introduced grasses along a nutrient gradient. Austral Ecol 28:491-498

Gustafson DJ, Gibson DJ, Nickrent DL (2004) Competitive relationships of Andropogon gerardii (Big bluestem) from remnant and restored native populations and select cultivated varieties. Funct Ecol 18:451-457

Hegarty CA, McAdam JH, Cooper A (1994) Factors influencing the plant species composition of hedges - implications for management in environmentally sensitive areas. Ed. Boatman N. In: Field margins: integrating agriculture and conservation monograph 58. BCPC Publications, Surrey, pp 227-234

Hunter ME, Omi PN (2005) Seed supply of native and cultivated grasses in pine forests of the southwestern United States and the potential for vegetation recovery following wildfire. Plant Ecol 183:1-8

Hunter ME, Omi PN (2006) Response of native and exotic grasses to increased soil nitrogen and recovery in a postfire environment. Restor Ecol 14(4):587-594

Knapp AK, Hamerlynck EP, Ham JM, Owensby CE (1996) Responses in stomatal conductance to elevated $\mathrm{CO}_{2}$ in 12 grassland species that differ in growth form. Vegetation $125: 31-41$

Low AB, Rebelo AG (1998) Vegetation of South Africa, Lesotho and Swaziland. Department of Environmental Affairs and Tourism (DET), Pretoria

Milton SJ (2004) Grasses as invasive alien plants in South Africa. S Afr J Sci 100:69-75

Moll EJ, Bossi L (1984) Assessment of the extent of the natural vegetation of the fynbos biome of South Africa. S Afr J Sci 80:355-358

Mucina L, Rutherford MC (eds) (2006) The vegetation of South Africa, Lesotho and Swaziland. SANBI, Pretoria, $804 \mathrm{p}$

Newton IP, Knight RS (2005) The use of Landsat imagery for the identification of the remaining West Coast Renosterveld fragments, Western Cape Province, South Africa. S Afr J Bot 71:67-75

Paschke MW, McLendon WT, Redente EF (2000) Nitrogen availability and old-field succession in a shortgrass steppe. Ecosystems 3:144-158

Ratlabala ME (2003) An overview of South Africa's mineral based fertilizers. Retrieved from URL: http://www.dme. gov.za/pdfs/minerals/r41.pdf dated 20 October 2009

Read DJ, Mitchell DT (1983) Decomposition and mineralisation processes in mediterranean-type ecosystems and in heathlands of similar structure. In: Kruger FJ, Mitchell DT, Jarvis JUM (eds) Mediterranean-type ecosystems: the role of nutrients. Springer, Berlin

Rejmánek M, Richardson DM (1996) What attributes make some plant species more invasive? Ecology 77:16551661

Shiponeni NN, Milton SJ (2006) Seed dispersal in the dung of large herbivores: implications for restoration of Renosterveld shrubland old fields. Biodiv Conserv 15:3161-3175

SPSS (1997) SPSS Base7.5 application guide. SPSS, Chicago, p 389

Stock WD, Allsopp N (1992) Functional perspective of ecosystems. In: Cowling R (ed) The ecology of fynbos: nutrients, fire and diversity. Oxford University Press, Oxford, pp 241-259

Suding KN, LeJeune KD, Seastedt TR (2004) Competitive impacts and responses of an invasive weed: dependencies on nitrogen and phosphorus availability. Oecologia 141:526-535

van den Berg LJ, Tomassen HB, Roelofs JG, Bobbink R (2005) Effects of nitrogen enrichment on coastal dune grassland: a mesocosm study. Environ Pollut 138:77-85

van Oudstshoorn F (1992) Guide to grasses of South Africa. Briza publications, Pretoria, p 216 
von Hase A, Rouget M, Maze K, Helme N (2003) A fine-scale conservation plan for Cape lowlands Renosterveld: Technical Report (Main Report). CCU 2/03, Cape Conservation Unit: Botanical Society of South Africa

Watson L, Dallwitz MJ (1992) The grass genera of the world: descriptions, illustrations, identification, and information retrieval; including synonyms, morphology, anatomy, physiology, phytochemistry, cytology, classification, pathogens, world and local distribution, and references. Retrived from URL: http://delta-intkey.com on 25 November 2008

Westman WE (1990) Managing for biodiversity: unresolved science and policy questions. Bioscience 40:26-33
Wikum DA, Shanholtzer GF (1978) Application of the BraunBlanquet cover abundance scale for vegetation analysis in land development studies. Environ Manag 2(4):323-329

Yelenik SG, Stock WD, Richardson DM (2004) Ecosystem level impacts of invasive Acacia saligna in the South African Fynbos. Restor Ecol 12(1):44-51

Zavaleta ES (2006) Shrub establishment under experimental global changes in California grassland. Plant Ecol 184(1): 53-56 